\title{
Optimization of Levan Production by Zymomonas mobilis
}

\author{
V. K. Ananthalakshmy and P. Gunasekaran* \\ Department of Microbial Technology, School of Biological Sciences, Madurai Kamaraj University, Madurai-625 \\ 021 , India
}

\begin{abstract}
Effect of different fermentation conditions on levan production by Zymomonas mobilis B-4286 was studied. Levan production increased from 5.7-g/l to $12.6-\mathrm{g} / \mathrm{l}$ with an increase in initial sucrose concentration (50-150 g/l). Above $15 \%$ (20 and 25\%) sucrose concentration, there was no increase in the biomass. The sucrose hydrolysis and levan production occurred even in the absence of significant growth of cells. Maximum amount of levan was produced $(14.5 \mathrm{~g} / \mathrm{l})$ at $\mathrm{pH} 5$ and $15 \mathrm{~g} / \mathrm{l}$ at $25^{\circ} \mathrm{C}$ temperature. At temperature between $35^{\circ} \mathrm{C}$ and $40^{\circ} \mathrm{C}$, levan production was not detected. Presence of glucose in the medium considerably reduced levan production (2.8 g/l) than fructose $6.7 \mathrm{~g} / \mathrm{l}$.
\end{abstract}

Key words: Levan, Levansucrase, Sucrase, Zymomonas mobilis

\section{INTRODUCTION}

Levan is a natural polymer of fructose with $\beta 2-6$ linkage. Many microorganism such as Bacillus subtilis, Aerobacter levanicum, Erwinia herbicola, Streptococcus salivarius and Zymomonas mobilis produce levan of high molecular weight when grown on sucrose media. Levan has potential commercial importance as fructose sweetener, thickening agent in food industry, antitumor agent (Carols et.al. 1991, Calazans et.al. 1997) and pharma-ceutical application. Although the levan has potential application, the amount of the levan produced is not equal to the other biopolymers such as dextran and xanthan. This is mainly due to the inefficiency of the producer organism. Among many levan-producing organisms, Z. mobilis is considered as a potential candidate for largescale production of levan. The amount of the levan production during fermentation of sucrose and by a flocculent strain of Z. mobilis was reported (Reiss and Hartmeier,1990). Recently, enzymatic production of levan by levansucrase from a recombinant of Escherichia coli overexpressing cloned levansucrase gene of $Z$. mobilis has been reported (Song and Rhee, 1994). In this paper, we report the effect of substrate concentration $\mathrm{pH}$, temperature and other fermentation conditions on the production of levan from sucrose.

\section{MATERIALS AND METHODS}

Organism and culture condition: Z. mobilis B - 4286 was obtained from NRRL, Peoria, Illinois. The culture was maintained on agar plates with RM medium containing (g/l) glucose-20; yeast extract-10 and $\mathrm{KH}_{2} \mathrm{PO}_{4}-2(\mathrm{pH}$ 6). It was routinely grown at $30^{\circ} \mathrm{C}$ without agitation. In fermentation studies, the glucose was replaced with sucrose (50-250 g/l).

Batch fermentation: Batch fermentation was carried out at $30^{\circ} \mathrm{C}$ with $100-\mathrm{ml}$ fermentation medium in $250 \mathrm{ml}$ Erlenmeyer flask, inoculated with $10 \% \mathrm{v} / \mathrm{v}$ of seed culture. Samples were withdrawn at regular intervals and analyzed for levan, biomass, ethanol, reducing sugars, residual sucrose, sucrase and levan forming activity.

Analytical methods: Biomass was estimated after removal of the levan and suspending the cells in $0.85 \% \mathrm{w} / \mathrm{v}$ sodium chloride solution and measuring the absorbance at $550 \mathrm{~nm}$.

\footnotetext{
* Author for correspondence
} 
The corresponding dry weight of cells was obtained from the established standard curve of absorbance against dry weight of cells (Kamini and Gunasekaran, 1991). Residual sucrose was estimated by the phenol sulfuric acid method (Dubois, et.al. 1956). The reducing sugar was estimated by 3-5 Dinitrosalicylic acid method (Miller 1959). Levan was separated by ethanol precipitation, hydrolyzed in $0.1 \mathrm{~N} \mathrm{HCl}$ at $100^{\circ} \mathrm{C}$ for $30 \mathrm{~min}$. and estimated as fructose units (Avigad 1968). Ethanol was estimated by the method of (Caputi et.al.1968). Sucrase activity was determined by the method of (Somogyi 1952).

Enzyme source and assay: The culture was grown for $16 \mathrm{~h}$ and cells were harvested at 5000 rpm for $10 \mathrm{~min}$. The supernatant was used as enzyme source. For sucrase assay the reaction mixture contains $25 \mu \mathrm{l}$ of enzyme, $250 \mu \mathrm{l}$ of $1 \mathrm{M}$ sucrose (in Sodium acetate buffer $\mathrm{pH} 5$ ) and 725 $\mu \mathrm{l}$ buffer incubated for half an hour at $30^{\circ} \mathrm{C}$ and the reducing sugar liberated was assayed. For levansucrase assay the above reaction mixture was incubated for $2 \mathrm{~h}$ at $30^{\circ} \mathrm{C}$ and turbidity was measured and the concentration of levan formed was determined from a standard curve. The sucrase activity was expressed as one $\mu \mathrm{g}$ of glucose released in one minute under experimental conditions. Levan forming activity was expressed as one $\mu \mathrm{g}$ of levan formed in one minute under experimental conditions.

\section{RESULTS AND DISCUSSION}

Effect of sucrose concentration: The effect of sucrose concentration (50-250 g/l) on the levan production by Z. mobilis b4286 is shown in Fig.1. Levan production increased from $5.7 \mathrm{~g} / \mathrm{l}$ to $12.6 \mathrm{~g} / \mathrm{l}$ and biomass $1.17-2.3 \mathrm{~g} / \mathrm{l}$ by the increase in concentration of sucrose from 50-150 g/l at $16 \mathrm{~h}$ with increase in concentration of sucrose from $50-150 \mathrm{~g} / \mathrm{l}$ at $16 \mathrm{~h}$.
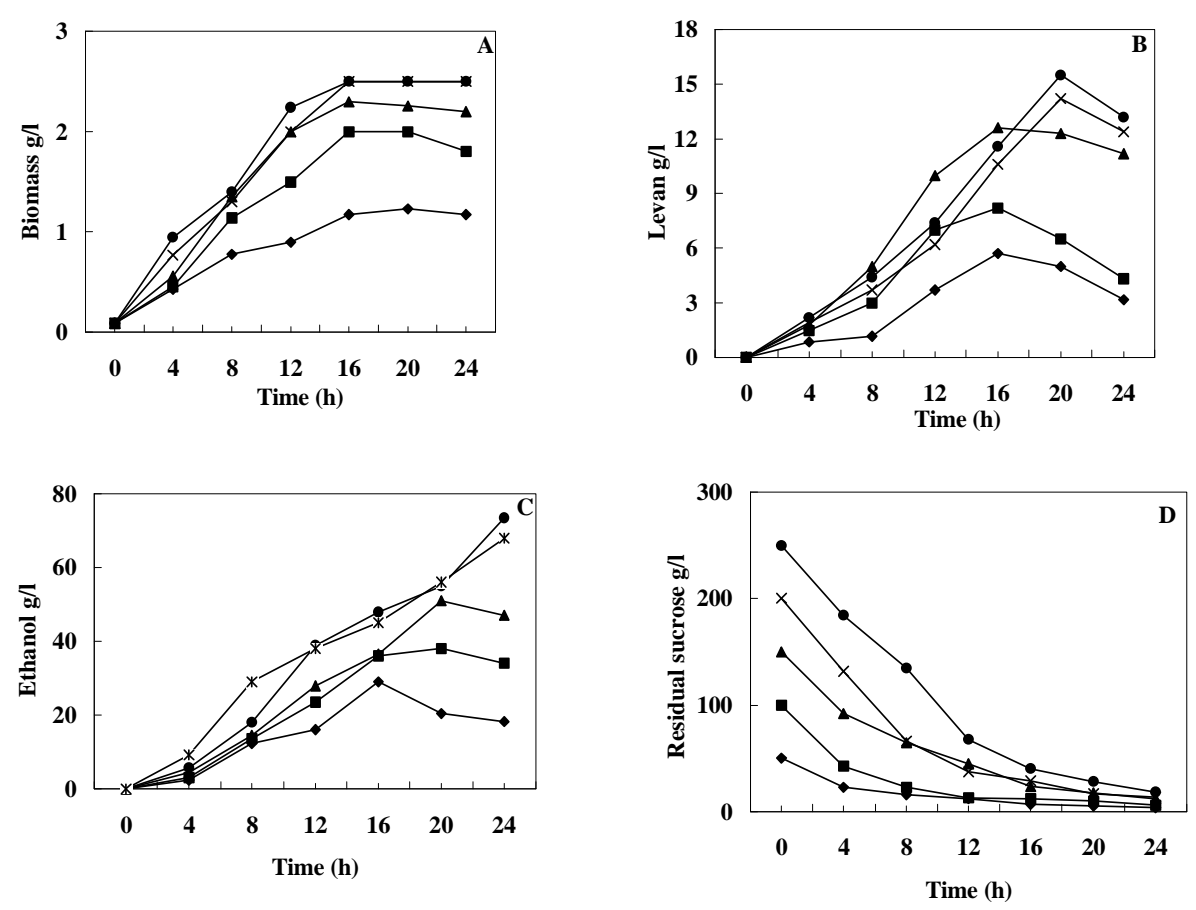

Figure 1. Effect of sucrose concentration on fermentation kinetics of Z. mobilis B4286, Sucrose (•) $5 \%$ ( ) $10 \%(\Delta) 15 \%$ (x) $20 \%$ (•) $25 \%$ 
Later the concentration of levan decreased. This reduction could be due to a levanase type of activity exhibited by the extracellular levansucrase (Yanase et al. 1992). Further increase in sucrose concentration (200-250 g/l), resulted in reduced amount of levan production in $16 \mathrm{~h}$. But the levan production was continued further and resulted in increased concentration of levan. Maximum concentration of levan (15.5$\mathrm{g} / \mathrm{l})$ was produced at $20 \mathrm{~h}$ from $250 \mathrm{~g} / \mathrm{l}$ sucrose. But increasing the sucrose concentration above $150 \mathrm{~g} / \mathrm{l}$ did not increase the biomass production $(2.3-2.5 \mathrm{~g} / \mathrm{l})$.
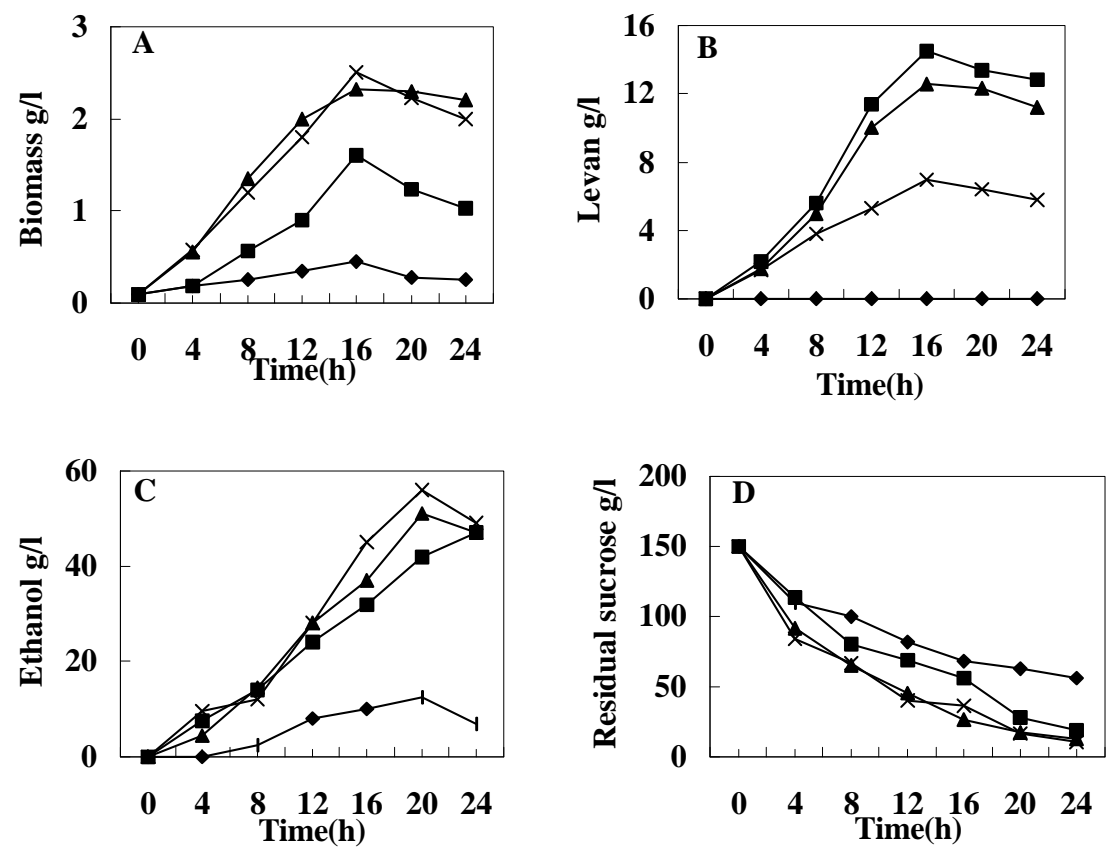

Figure 2. Effect of pH on fermentation kinetics of Z. mobilis B4286 pH (•) 4 ( ) 5 ( $\Delta$ ) 6 (x) 7

These results suggested that at the increased sucrose concentration, levan production occurred even in the absence of any significant growth of the cells.

Effect of fermentation pH: The effect of initial $\mathrm{pH}$ of the fermentation on the production of levan is shown in (Fig. 2). The levan produced from sucrose $(150 \mathrm{~g} / \mathrm{l})$ was maximum $(14.5 \mathrm{~g} / \mathrm{l})$ at an initial $\mathrm{pH}$ of 5 . At the initial $\mathrm{pH}$ of 4 the levan was not produced while at $\mathrm{pH} 7$ the levan production was reduced to $6.8-\mathrm{g} / \mathrm{l}$. The absence of levan production at $\mathrm{pH} 4$ could be attributed to the minimum growth of thecells $(0.45-\mathrm{g} / \mathrm{l})$. Moreover, at $\mathrm{pH} 4$ the levanforming activity of the levansucrase was lesser than the sucrose hydrolysing activity (Crittenden and Doelle, 1994). Although the amount of biomass (2.0-
$2.3 \mathrm{~g} / \mathrm{l}$ ) produced in $16 \mathrm{~h}$ was higher at $\mathrm{pH} 6-7$, the levan produced was lower than that was produced at initial $\mathrm{pH}$ 5. This also confirm the earlier report that the maximum levan production by Z. mobilis at pH 5 (Park et.al., 1983 and Reiss and Hartmeier,1990). This may be due to that the $\mathrm{pH} 5$ is optimum of levansucrase for levan synthesis. Further at higher $\mathrm{pH}$, the oligosaccharide formed is more than levan (Yanase et.al., 1992).

Effect of temperature: The levan formation during sucrose fermentation at different temperatures $\left(25-40^{\circ} \mathrm{C}\right)$ was studied and the results are shown in Figure3. The production of levan was more $(15-\mathrm{g} / \mathrm{l})$ at $25^{\circ} \mathrm{C}$ fermentation while no levan was formed during fermentation at $35^{\circ} \mathrm{C}$ and $40^{\circ} \mathrm{C}$ on the 

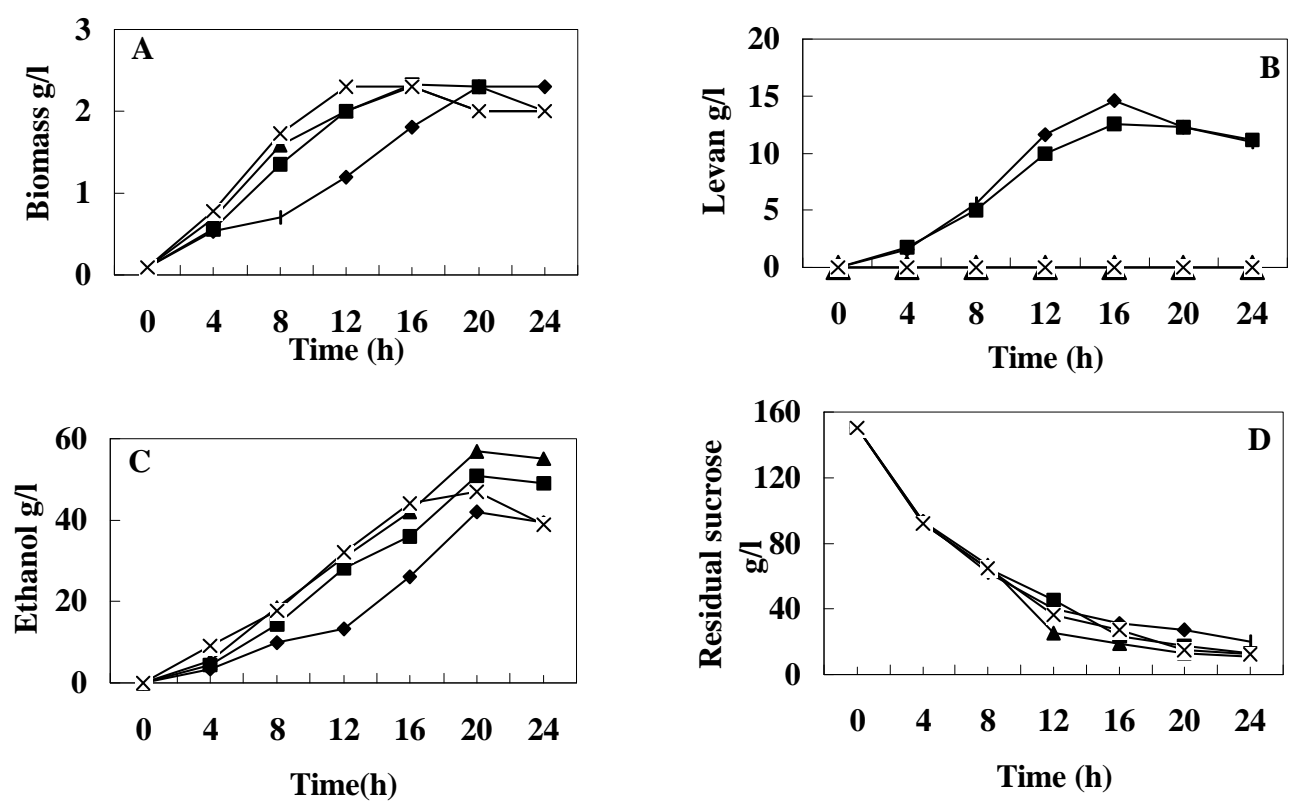

Figure 3: Effect of fermentation temperature on levan production by Z. mobilis $\mathrm{B} 4286,(\bullet) 25^{\circ} \mathrm{C}$ ( ) $30^{\circ} \mathrm{C}(\Delta) 35^{\circ} \mathrm{C}$ (x) $40^{\circ} \mathrm{C}$.

contrary ethanol production increased (48.2$57 \mathrm{~g} / 1)$ as the temperature increased from 25 $35^{\circ} \mathrm{C}$ and decreased to $47 \mathrm{~g} / 1$ at $40^{\circ} \mathrm{C}$. but sucrase activity was observed at these temperatures. However, the biomass produced at $25^{\circ} \mathrm{C}$ and $40^{\circ} \mathrm{C}$ were not significantly different $(2.3 \mathrm{~g} / \mathrm{l}$ at 25 and $2.0 \mathrm{~g} / 1$ at $40^{\circ} \mathrm{C}$ ). The loss of levan production by $Z$. mobilis during fementation at 35 and $40^{\circ} \mathrm{C}$ could be due to: a) inactivation of the extracellular levansucrase but not the extracellular sucrase at elevated temperature, $b$ ) the levansucrase loses its ability to synthesis levan irreversibly but retaining sucrose hydrolyzing activity. The enzyme levansucrase irreversibly lost the 1 evanforming ability at $35^{\circ} \mathrm{C}$ while retaining the sucrose hydrolyzing ability (Crittenden and Doelle, 1994).

In order to confirm the above, the amount sucrase and levanforming activity produced in the extracellular fraction was determined. (Figure 4) Levanforming enzyme produced was high at $25^{\circ} \mathrm{C}$ fermentation $(148 \mathrm{U} / \mathrm{mg}$ of cell mass). However, when temperature of fermentation was increased to $40^{\circ} \mathrm{C}$ there was a decrease in enzyme production $(26 \mathrm{U} / \mathrm{mg}$ of cell mass). However, sucrose hydrolyzing enzyme increased from $1.3-1.7 \mathrm{U} / \mathrm{mg}$ cell mass as the fermentation temperature increased from 25$35^{\circ} \mathrm{C}$, after that at $40^{\circ} \mathrm{C}$ it decreased to $1.3 \mathrm{U} / \mathrm{mg}$ cell mass.

The levan forming and sucrose hydrolysing activity were determined at different temperatures ranging from 25 to $40^{\circ} \mathrm{C}$ (Fig. 5). Levan forming activity decreased from $327 \mathrm{U} / \mathrm{ml}$ to $164 \mathrm{U} / \mathrm{ml}$ as the temperature increased from 25 to $40^{\circ} \mathrm{C}$. While as sucrose hydrolysing activity increased from $3.2-4.2 \mathrm{U} / \mathrm{ml}$ as the temperature increased from $25-35^{\circ} \mathrm{C}$, and at $40^{\circ} \mathrm{C}$ it decreased to $3.8 \mathrm{U} / \mathrm{ml}$.

To determine the stability of levanforming and sucrose hydrolysing enzyme activity, the enzyme was pre-incubated for $12 \mathrm{~h}$ at different temperature $25^{\circ} \mathrm{C}-40^{\circ} \mathrm{C}$ and sucrose hydrolysis 
and levanforming activity were determined at $30^{\circ} \mathrm{C}$ using this pre-incubated enzyme (Fig. 5). From these results it is confirmed that the enzyme was stable for its levanforming activity at high temperature but sucrose hydrolysis is preferred at high temperature and low temperature favored trans-fructosylation (levan

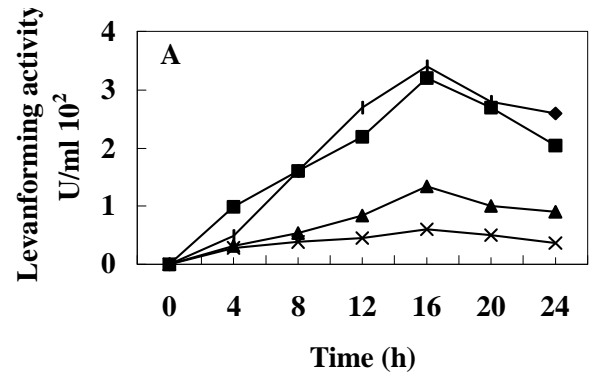

formation). Several authors have also reported that levan production was more at low temperature (Lyness and Doelle 1983, Reiss and Hartmeier 1990, Yoshida et.al. 1990). The lower temperature is suitable for levansucrase for transfructosylation (Yanase et.al. 1992).

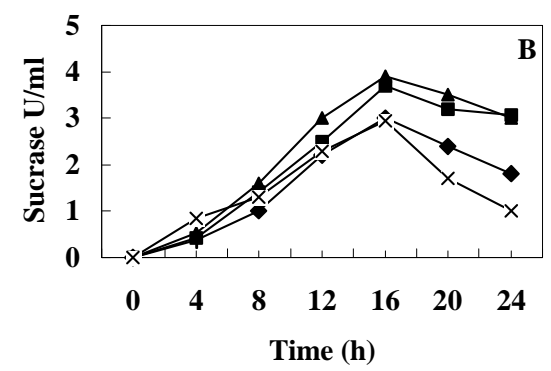

Figure 4: Effect of temperature on synthesis of levan forming (A) and sucrase (B) enzyme of Z. mobilis B4286 ( $25^{\circ} \mathrm{C}(\mathrm{s}) 30^{\circ} \mathrm{C}(\Delta) 35^{\circ} \mathrm{C}(\mathrm{x}) 40^{\circ} \mathrm{C}$.
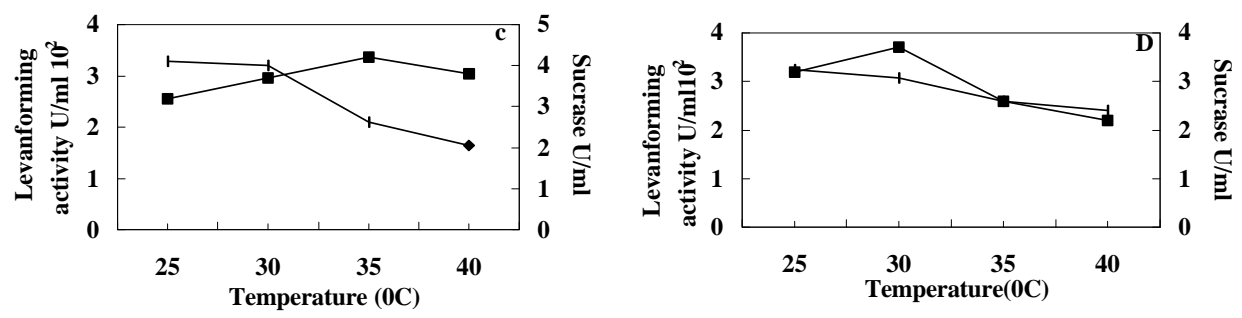

Figure 5: Levan forming and sucrose hydrolysing activity at different temperature (C) Effect of temperature on the stability of levan forming and sucrose hydrolysing activity (D) ( )Levan forming activity ( ) sucrose hydrolysing activity

Effect of addition of glucose and fructose on levan formation: The accumulation of monomeric sugars lower the levan production (Viikari and Gisler, 1986). Therefore, glucose (or) fructose was added into the medium to alter (increase (or) decrease) the ratio of glucose to fructose in the medium and studied the levan production by Z. mobilis (Figure 6). Addition of either glucose (or) fructose $(150 \mathrm{~g} / \mathrm{l})$, into the fermentation medium reduced the levan production from $12.6 \mathrm{~g} / \mathrm{l}$ to $2.8 \mathrm{~g} / \mathrm{l}$ in $16 \mathrm{~h}$ ( in glucose addition) and $6.7 \mathrm{~g} / 1$ (in fructose addition)with the decrease in biomass production from $2.3 \mathrm{~g} / \mathrm{l}$ to $1.9 \mathrm{~g} / \mathrm{l}$ and $1.45 \mathrm{~g} / \mathrm{l}$ respectively. Continuation of the fermentation for a longer period $(24 \mathrm{~h})$ resulted in almost same amount of biomass production in glucose added medium.

Therefore, levan production was strongly affected by the glucose addition than fructose. In continuous fermentation of sucrose, the addition of 5 to $10 \mathrm{~g} / \mathrm{l}$ of glucose reduced the levan formation (Viikari and Linko, 1986). Inhibition of levansucrase by glucose was responsible for the 10-fold difference in levan production in batch and continuous fermentation of sucrose. The results revealed that addition of glucose 50 and $100 \mathrm{~g} / \mathrm{l}$ into the medium the cell mass production was not significantly different but in $150 \mathrm{~g} / \mathrm{l}$ addition, 1.22-fold reduction was 

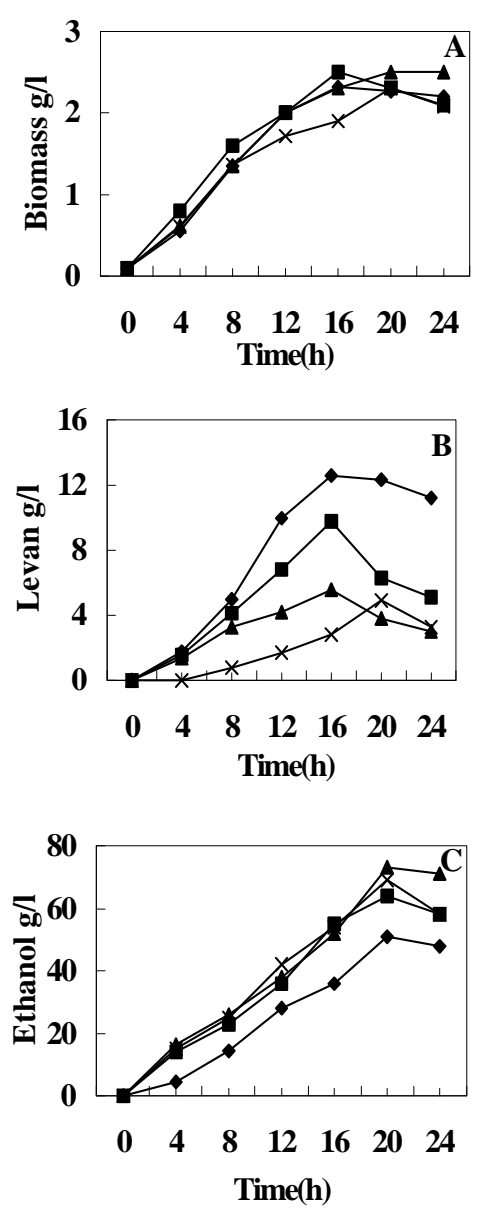
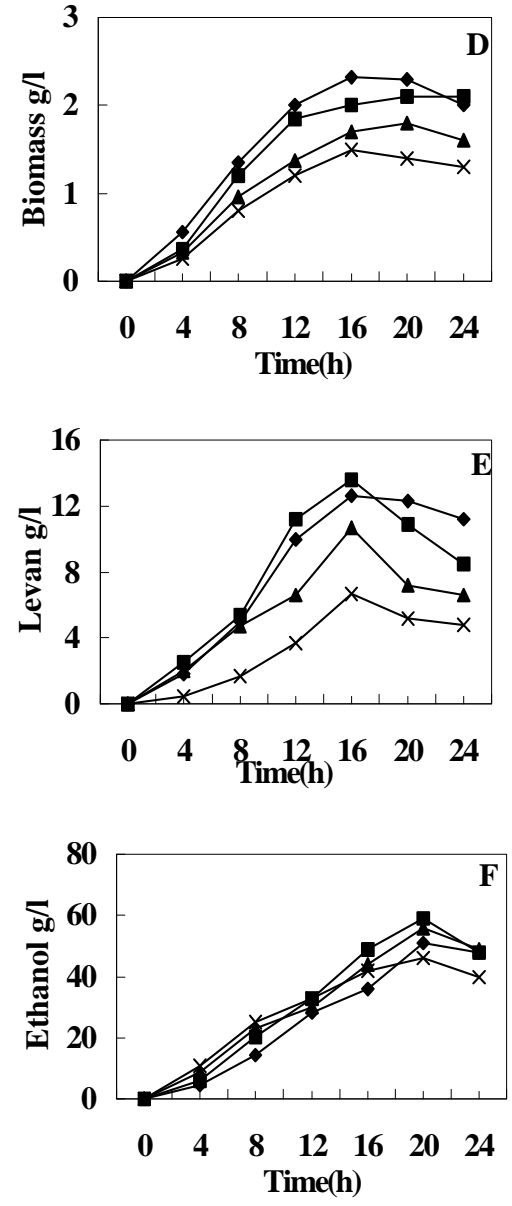

Figure 6: Effect of addition of glucose (A-C) and Fructose (D-F) on levan production by Z. mobilis B4286. $(\diamond) 150 \mathrm{~g} / \mathrm{l}$ sucrose, Glucose (or) Fructose ( ) $50 \mathrm{~g} / \mathrm{l}(\Delta) 100 \mathrm{~g} / \mathrm{l}(\times)$ 150g/l.

found. At the similar condition with fructose 50, 100 and $150 \mathrm{~g} / \mathrm{l}$ addition, the cell mass reduction was 1.2, 1.4 and 1.6-fold. The ethanol production was increased from $51 \mathrm{~g} / 1$ to 64,73 and $69 \mathrm{~g} / \mathrm{l}$ and 59,56 and $46 \mathrm{~g} / \mathrm{l}$ with 50-150 g/l addition of glucose and fructose. Although the levan is a polymer of fructose units, the high concentration of fructose in the medium did not increase the levan production. The increase of fructose to glucose ratio favored the production of sorbitol than levan (Favela-Torres and Baratti, 1987).

\section{ACKNOWLEGDEMENTS}

Authors thank The Council of Scientific and Industrial Research, New Delhi, and Department of Science and Technology, New Delhi, for grants Nos. CSIR 38/0912/EMR II and dst/sp/so/a25/96, respectively.

\section{RESUMO}

O efeito de diferentes condições de fermentação na produção de levan por Zymomonas mobilis B-4286 foi estudado. A produção de Levan aumentou de 5.7$\mathrm{g} / \mathrm{l}$ a $12.6-\mathrm{g} / \mathrm{l}$ com o aumento da concentração inicial de sacarose (50-150 g/l). Acima de 15\%, 20 e 25\% a 
concentração de sacarose, não propiciou nenhum acréscimo na formação de biomassa. A hidrólise da sacarose e produção de Levan ocorreram de forma normal na ausência de um crescimento celular significativo. A concentração máxima de levan produzida foi $(14.5 \mathrm{~g} / \mathrm{l}) \mathrm{em} \mathrm{pH} 5,15 \mathrm{~g} / 1$ a $25^{\circ} \mathrm{C}$. Na temperatura entre $35^{\circ} \mathrm{C}$ e $40^{\circ} \mathrm{C}$, não ocorreu a produção de levan. A presença de glicose no meio de cultivo reduziu consideravelmente a produção média de levan $(2.8 \mathrm{~g} / \mathrm{l})$ bem como a de frutose $(6.7 \mathrm{~g} / \mathrm{l}$.).

\section{REFERENCES}

Clazans, G. M. T., Lopes, C. E., Lima, R. M. O. C. and Defranca, F. P. (1997), Antitumor activity of levans produced by Zymomonas mobilis strains. Biotechnol. Lett., 19, 19-21

Caputi, A., Veda, M. and Brown, T. (1968), Spectrophotometric determination of ethanol in wine. American J. Enol. Viticul., 19, 160165

Carlos, T. F., Lopes, C. E., Rois, E. M., Calazans, G. M. T., Souza, I. A., Noronha, T. J. and Costa, T. C. F. S. (1991), Producao de levana por Zymomonas mobilis em escala laboratorial. In 21st Brazilian congress of chemistry, Recife.

Crittenden, R.G. and Doelle, H.W. (1994), Identification and characterization of the extracellular sucrases of Zymomonas mobilis UQM 2716 (ATCC 39676). Appl. Microbiol. Biotechnol., 41, 302-308.

Dubois, M., Gilles, K.A., Roberts, P.A. and Smith, F. (1956), Colorimetric method for determination of sugars and related substances, Anal Chem., 25, 350-356.

Favela-Torres, E. and Baratti, J. (1987), The effect of $\mathrm{pH}$, temperature and sucrose concentration on high productivity continuos ethanol fermentation using $Z$.mobilis. Appl. Microbiol Biotechnol., 27, 121-128

Gunasekaran, P. and Kamini, N. R. (1991), High ethanol productivity from lactose by immobilized cells of Kluyveromyces fragilis and Zymomonas mobilis. World J. Microbiol. Biotechnol., 7, 551-556

Lyness, E.W., and Doelle, H.W. (1983). Levansucrase from Zymomonas mobilis. Biotechnol. Lett., 5, 345-350.
Miller, G. L. (1959), Use of DNS reagent for the determination of reducing sugars. Anal Chem., 31, 426-428.

Park, Y. K., Mortatti, M. P. L. and Sato, H. H. (1983), Study on levan formation during fermentation of Zymomonas mobilis on sucrose. Biotechnol. Lett., 5, 515-518

Preziosi, L., Michael, G.P.F. and Baratti, J. (1990a), Characterization of sucrose hydrolysing enzymes of Zymomonas mobilis. Arch. Microbiol., 153, 181-186.

Preziosi, L., Michael, G.P.F. and Baratti, J. (1990b), Sucrose metabolism in Zymomonas mobilis, Production and localization of sucrase and levansucrase activities. Can J Microbiol., 36, 159-163.

Reiss, M. and Hartmeier, w. (1990), Levan production with a flocculent strain of Zymomonas mobilis Food. Biotechnol., 4,6975

Somogyi, M.J. (1952), Notes of sugar determination. J. Biol. Chem., 195, 19-23.

Song, K. B. and Rhee, S. K. (1994), Enzymatic synthesis of levan by Zymomonas mobilis. levansucrase overexpressed in Escherichia coli. Biotechnol. Lett., 16, 1305-1310

Viikari, L and Gisler, R. (1986), By-products in the fermentation of sucrose by different Zymomonas strains. Appl Microbiol. Biotechnol., 23, 240-244

Viikari, L. (1984), Formation of levan and sorbitol from sucrose by Zymomonas mobilis. Appl. Microbiol. Biotechnol., 19, 252-255

Viikari, L. and Linko, M. (1986), Rate and yield limiting factors in continuos fermentation of sucrose by Zymomonas mobilis. Biotechnol. Lett., 8, 139-144

Yanase, H., Iwata, M., Nakahigashi, R., Kita, K., Kato, N., and Tonomura, K.(1992), Purification, crystallization and properties of the extracellular levansucrase from Zymomonas mobilis Biosci. Biotechnol. Biochem., 56, 1335-1337

Yoshida, Y., Suzuki, R. and Yagi, Y. (1990), Production of levan by a Zymomonas sp. J. Ferm. Bioeng., 70, 269-271
Received August 30, 1999; Revised September 19, 1999; Accepted September 28, 1999. 